\title{
Understanding the impact of financial sustainability on South African municipalities
}

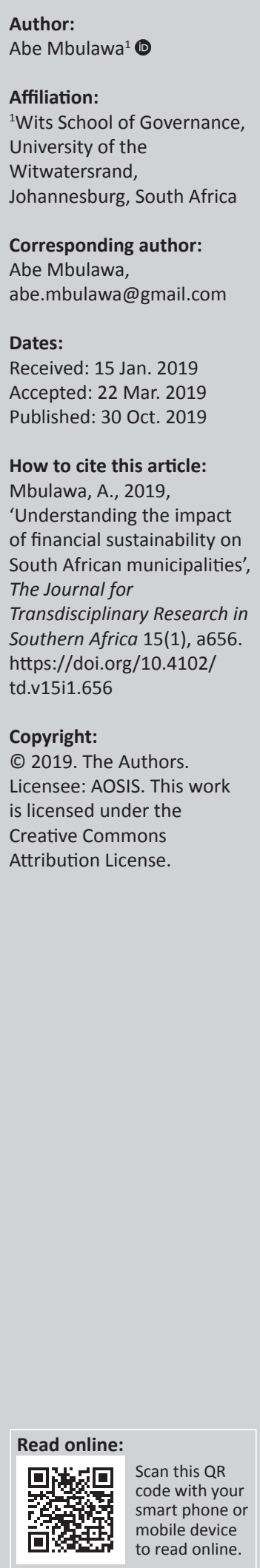

This article acknowledges the lack of skills and poor financial governance within South African municipalities but argues that these factors are an insufficient explanation of their increasing fiscal distress, which was found at over $90 \%$ by 2016. It employs the concept of financial condition to construct an econometric function for South African local government. This financial condition function confirms that the fiscal framework of South African local government is distressed. The article further concludes that as service delivery improves, so does the fiscal distress. This applies even to municipalities that receive audit outcomes without material findings. As an illustration, the article uses the collective debt incurred by municipalities to Eskom - the energy utility company. The article argues that it is mathematically impossible to settle this debt within the current local government fiscal framework. The conclusion confirms the importance of constructing the financial condition function as an enabler for improved local government financial health.

Keywords: Financial condition; service delivery solvency; good financial governance; fiscal framework; fiscal distress; municipal sustainability; audit outcomes.

\section{Introduction}

The poor financial state of municipalities is well researched and documented across the world, starting with the United States since the New York fiscal crisis of the 1970s (Clark, Ferguson \& Shapiro 1982), as well as in recent times (Wang, Dennis \& Tu 2007). Based on the essentiality of municipal functions, similar studies have been conducted in other countries, such as Israel (Ben-Elia 1998; Carmeli \& Cohen 2001; Razin 1998), Greece (Kalchheim 1997), Czechoslovakia (Hrüza 2013) and Italy (Padovani, Manes Rossi \& Orelli 2010). In South Africa, the Local Government Turnaround Strategy (Republic of South Africa [RSA], Department of Co-operative Governance and Traditional Affairs [COGTA] 2009a) has provided valuable insights into the country's poor municipal fiscal health, such as the lack of skills and poor financial governance. By 2016, the number of financially distressed municipalities stood at 93\% (Afrika Rating 2016). In concerted efforts to address this deterioration, the Auditor-General of the country released findings that show deficiencies, increasing dysfunctionality and minimal increase in the number of clean audits. In South Africa, a clean audit is defined as the three pillars of financial reporting, performance outcomes and compliance to laws and regulations - all without material findings (RSA 2004).

The deficit in skills needs to be understood in the context of the lack of political desire to appoint highly professional senior managers. This is because they are less likely to implement questionable instructions than those who are beholden to their political principals usually through cadre deployment (Netshitendzhe 1996). Cadre deployment is the:

\footnotetext{
.. appointment of government party loyalist to an institution, as a means of circumventing public accountability and bringing the institution under the control of the party, as opposed to the state. (Van Onselen 2012:1)
}

This means that the Department of Cooperative Governance and Traditional Affairs cannot address the skills deficit without considering the impact of cadre deployment on municipal governance (Twala 2014). Unlike other spheres of government and state-owned enterprises, at local government level, the executive mayor, through Section 56 of the Local Government Municipal Structures Act (RSA 1998), is empowered to implement the political mandate doing away with the need for cadre deployment within the administration. However, cadre deployment is not only an African National Congress (ANC) practice. A perusal of the websites of leading political parties (i.e. the Democratic Alliance and the Economic Freedom Fighters) shows that although they do not have similar cadre deployment policies, they have similar recruitment practices as the ANC. 
This article excludes the lack of skills and investigates systematic fiscal failure that results in negative audit outcomes as reported by the Auditor-General.

Based on the Auditor-General's reports between 2006/2007 and the 2011/2012 administrative years, Powell et al. (2014) concluded that $100 \%$ of clean audits will occur in the 2022/2023 fiscal year. Given the financial environment, Powell extrapolated that in the 2016/2017 fiscal year, South Africa should have achieved $60 \%$ clean audits. In reality, only $13 \%$ of the municipalities received clean audits in the 2016/2017 fiscal year. This means that the expected goal of a $100 \%$ success rate will have to be extended far beyond the 2022/2023 fiscal year. This leads to the following question: Will this elusive target be met, and if not, what are the influencing factors? The Auditor-General's report of 2016/2017 highlighted three key problems that need to be resolved in order to meet the elusive target: (1) addressing the lack of consequence management that leads to (2) noncompliance that leads to (3) irregular expenditure (RSA, AGSA 2017). The cycle repeats annually, resulting in increased irregular expenditure and poor financial governance.

The impact on municipal financial sustainability was raised in the Local Government Turnaround Strategy (LGTAS) report of 2009 (RSA, COGTA 2009a). This was a result of the limited success of Project Consolidate (2004-2009). A number of measures were put in place, including the Local Government Municipal Regulations on Minimum Competency Levels (RSA, Department of Finance [DOF] 2007) and the Local Government Municipal Regulations on Financial Misconduct Procedures and Criminal Proceedings of the Municipal Finance Management Act (MFMA) (RSA, DOF 2014).

Despite these measures, the ability of municipalities under the project LGTAS (2009-2014) to reach $30 \%$ of clean audits failed (Powell et al. 2014). To address this, the Back to Basics Programme was launched in September 2014 (RSA, COGTA 2014). Four years later, in 2018, the programme had achieved minimal success as predicted by Powell et al. (2014). In September 2018, the COGTA launched the Municipal Recovery Plan, also referred to as Back to Basics Programme II (Mkhize 2018). Its ability in arresting fiscal distress remains to be seen. However, the failed turnaround strategies since 2004 prompt the next question: besides poor financial governance and lack of skills, are there any other key factors that cause poor fiscal health of local government?

The remainder of this article is structured as follows: the 'Introduction' and 'The fiscal environment of South African local government' sections present a review and discussion relating to existing works from two perspectives: South African fiscal environment and financial condition. The 'Measure of financial condition' section deals with measurement of financial condition. The 'Data and modelling' section discusses the data presented in the article. The analysis and results are presented in the 'Analysis and results' section, followed by the 'Discussion' section that provides a general discussions of the study. The 'Limitations' section discusses the limitations of the article. The concluding remarks of the article are presented in the 'Conclusion' section.

\section{The fiscal environment of South African local government}

Local government, unlike the other two spheres of government (national and provincial), is the only arm that generates its own revenue to sustain its legislated mandate. This makes the economic (transactional structure) of local government aligned with state-owned enterprises, rather than with the other spheres of government that have an administrative structure (Nutt \& Backoff 1992). This transactional authority is derived from Section 156 of the Constitution of the Republic of South Africa (RSA 1996), Section 64 of the MFMA (RSA 2003) and Chapter 9 of the Local Government Municipal Systems Act (RSA, DOF 2000). The National Treasury MFMA Circular 64 (RSA 2012b) provides the local government fiscal framework that underpins a financially sustainable municipality. Its aim is to improve municipal financial health by maximising revenue collection while reducing inefficiency, costs and uncollectible debt (RSA, DOF 2012b). The circular offers a guideline for municipalities on how to accumulate surplus funds or cash-backed reserves through improving their financial health.

Good financial governance is prescribed under Section 216 in the Constitution of the Republic of South Africa (RSA 1996). This is enacted by Section 87 of the Public Finance Management Act (PFMA) (RSA 1999) through the establishment of the Accounting Standards Board (ASB). The ASB sets standards and guidelines for financial statements as mandated by Section 216(a) of the Constitution of the Republic of South Africa. It entails developing measures to ensure transparency by introducing Generally Recognised Accounting Practices (GRAP) in the three spheres of government as a mechanism of good financial governance. To further enhance good financial governance there is the In-Year Budgetary Monitoring process. This commences with monthly reporting prescribed in Section 71 of the MFMA (RSA 2003), followed by Section 52(d) for quarterly monitoring. Mid-year assessment is enabled through Section 72 of the MFMA (RSA 2003). At this point, budget adjustment is permitted to address reallocations and priority changes. Both quarterly and mid-year reporting includes service delivery performance. The three sets of reporting provide an oversight mechanism for the municipal council, COGTA and National Treasury. The objective of this good financial governance is to ensure financial sustainability of municipalities by proactively preventing fiscal distress. Schick (1988) defines four stages of financial health, as illustrated in Figure 1. When a local government is relaxed, it is prone to have vanity projects because of surplus funds. As the surplus funds deplete, it starts having chronic difficulties in balancing the budget. 


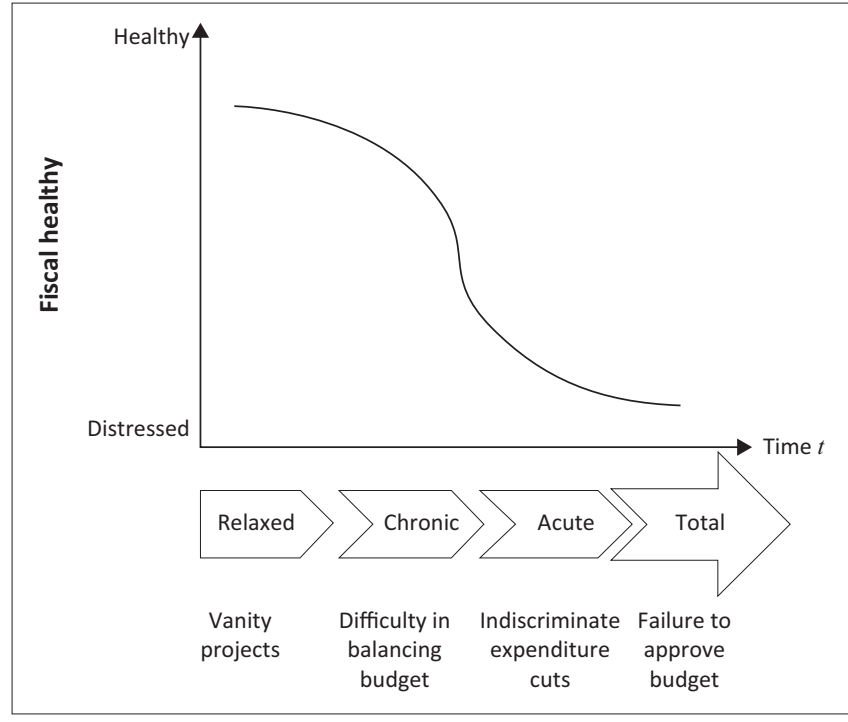

Source: Schick, A., 1988, 'Micro-budgetary adoptions to fiscal stress in industrialize democracies, Public Administration Review 48(January/February), 523-533. https://doi. org/10.2307/975515

FIGURE 1: Stages of financial health.

As this worsens, the municipality gets fiscally distressed in carrying out indiscriminate expenditure cuts at the expense of service delivery. When there is total distress, the municipality is unable to pass its budget and needs to be placed under administration.

In a situation where fiscal health is found to be in distress, remedy is sought. This is done by complementary invoking Section 139(5) of the Constitution of the Republic of South Africa (RSA 1996), Section 65(2)(f) of the MFMA (RSA 2003) and MFMA Circular 49 (RSA, DOF 2009). MFMA Circular 71 (RSA, DOF 2014) defines financial distress as:

\footnotetext{
... when a municipality fails to make payments when due and such failures amount to $2 \%$ of the municipality's operating budget for that year may indicate that the municipality is in serious breach of its obligations. (p. 2)
}

Municipal Finance Management Act Circular 71 (RSA, DOF 2014) provides a list of indicators for evaluating the financial position of a municipality flagging fiscal distress. The indicators consist of five singular ratios: (1) total debt to revenue (excluding grants), (2) debt service coverage ratio, (3) debt to net cash ratio, (4) cash flow interest coverage, and (5) liability management ratio. These ratios are analysed descriptively in the annual State of Local Government report, which forms part of the Auditor-General's and National Treasury's financial viability assessments.

It is noted that these indicators do not consider financial condition as defined by United States Governmental Accounting Standards Board (GASB) Statement No. 44 of 2004. It defines this as the government's capacity to fulfil its contractual obligations while continuing to provide services at both current and future states (USA, GASB 2004). Financial condition incorporates the concept of service delivery solvency, which is the ability of a municipality to provide services in accordance with legislative obligations, for current and future states. With respect to revenue generation, the cost of service delivery solvency is important for South Africa in that it has one of the highest unemployment rates in the world. This makes the concept of financial condition as important for South Africa as in the United States.

The absence of financial condition as part of National Treasury's policy has resulted in limited data and academic literature. Instead, lack of skills and poor governance (Schoeman 2011; Van der Waldt 2012) are accepted as the de facto cause of municipal distress. One of the first studies on financial condition was Ngwenya's (2010) study which was confined to three metropolitan councils in Gauteng between $2006 / 2007$ and $2008 / 2009$. This was followed by an article by Ncube and Vacu (2014) on 273 municipalities over the $2004 / 2005$ to $2010 / 2011$ fiscal years. However, Ncube and Vacu did not develop a composite index but applied Kloha's scale for financial health (Kloha, Weissert \& Kleine 2005). The most recent research conducted in this regard is by Coetzee and Kleynhans (2019), which focused on the financial conditions of 51 municipalities in KwaZulu-Natal from $2008 / 2009$ to $2014 / 2015$ using a methodology adopted from Ritonga's thesis (2014). While constructing composite scores for the individual municipalities, Coetzee and Kleynhans (2019) did not provide a financial condition function that can assist in determining the robustness of the local government fiscal framework.

\section{Measure of financial condition}

The GASB defines four key indicators of financial condition: cash solvency, budgetary solvency, long-term solvency and service-level solvency (USA, GASB 2004). The first three are standard financial indicators, while the fourth, servicelevel solvency, is specific to local government. The rationale behind financial condition is the determination of a mechanism that can allow prevention of fiscal emergencies. This enables prompt response to emergencies (Coe 2008; Groves, Godsey \& Shulman 1981; Kloha et al. 2005; Nollenberger 2003). Financial condition is therefore predictive in nature.

While financial condition in itself provides warnings about fiscal distress, the efficacy of the indicator is constrained by the measurement methodology. This challenge was addressed by the seminal work of Groves et al. (1981) on financial indicators for local government in which they proposed a practical methodology, 'Financial Trends Monitoring System' (FTMS). The FTMS was adopted by the National League of Cities (NLC) to provide fiscal positions of local governments as a means to gather their financial position on an annual basis. (The NLC is the United States' equivalent of the South African Local Government Association [SALGA]). Owing to it being an open financial system of both partial and uncontrollable fiscal environments, it is treated as a complex and unwieldy methodology comprising 47 ratios. To overcome this issue, Berne and Schramm (1986) argued that analysing the partially controllable fiscal environment provided sufficient data to determine the financial position 
of a municipality. The first of such methods was that of Brown's 10-point ratios (1993) that used general fund data, making it a closed financial system methodology. This was followed by Mercer and Gilbert's (1996) method and Chaney, Mead and Schermann's (2002) method. The adoption of the concept of financial condition in GASB Statement No. 44 (US, GASB 2004) led to several models, most notably Kloha et al.'s (2005) model that used general fund data with socioeconomic indicators, making it a pseudo-open financial system; Wang et al. (2007) and Maher and Nollenberger (2009) used general fund data similar to Brown (1993). To ensure better understanding, this article considers all related models as financial condition models, even those developed before the adoption of GASB Statement No. 44 in 2004.

The strength of Brown's 10-point test lies in its ability to evaluate the financial condition of local government utilising existing general fund data. The composite score assesses the financial condition of the municipality relative to the performance of other municipalities in the same basket; from among the worst to the best. This means that it does not provide an absolute interpretation of the local government, that is, whether it is financially healthy or financially distressed. Thus, if all the municipalities in the basket were financially unhealthy, then this would not be reflected, only showing the relative financial state of each municipality against those it is compared to. Another weakness of Brown's tool is that each ratio has equal weight, ignoring that some ratios have greater impact.

Despite its drawbacks, Brown's model (1993) has given rise to several offshoots, notably those of Chaney et al. (2002), Wang et al. (2007) and Maher and Nollenberger (2009). The latter initially built on the work of Brown's model opting to use Altman's (1968) multivariate discriminate analysis approach but applied linear regression. To be consistent with accounting practice, they applied FTMS ratios for the four GASB composite indicators. This gave rise to the $\mu$-matrix in Equation 1:

$[\mu]=\alpha+Y_{1} a, b+Y_{2} a, b, c+Y_{3} a, b, c, d+Y_{4} a, b, c, d, e$

$=\alpha+\alpha_{1} \Sigma Y_{1}+\alpha_{2} \Sigma Y_{2}+\alpha_{3} \Sigma Y_{3}+\alpha_{4} \Sigma Y_{4}+\varphi$

[Eqn 1]

Where:

- $\alpha=$ constant

- $\alpha_{1}=$ coefficient of Financial Condition Indicator

- $\mathrm{Y}_{1}=$ financial condition ratio as per GASB Statement No. 44

- $\varphi=$ error margin.

Maher and Nollenberger (2009) argued that the model constructs the composite matrix of $\mu$-scores of the municipalities using the composite ratios in Table 1. Notably, it provides absolute gradation of financial condition as an indicator of potential distress; the lower the score, the higher the distress.

\section{Data and modelling}

This study was limited to selecting one ratio for each of the four financial condition indicators mentioned in Table 1.
TABLE 1: Financial condition ratios.

\begin{tabular}{ll}
\hline Financial condition indicator & Ratio \\
\hline Cash solvency & $\mathrm{Y}_{1} \mathrm{a}-$ Cash ratio \\
& $\mathrm{Y}_{1} \mathrm{~b}-$ Liabilities ratio \\
& $\mathrm{Y}_{2} \mathrm{a}-$ Operating ratio \\
& $\mathrm{Y}_{2} \mathrm{~b}-$ Property tax revenue ratio \\
& $\mathrm{Y}_{2} \mathrm{c}-$ Intergovernmental revenue ratio \\
& $\mathrm{Y}_{3} \mathrm{a}-$ Fund balance ratio \\
& $\mathrm{Y}_{3} \mathrm{~b}-$ Outstanding general long-term debt ratio \\
& $\mathrm{Y}_{3} \mathrm{c}-$ Governmental debt service ratio \\
& $\mathrm{Y}_{3} \mathrm{~d}-$ Unfunded pension liability ratio \\
& $\mathrm{Y}_{4} \mathrm{a}-$ Outstanding general long-term debt per capita \\
& $\mathrm{Y}_{4} \mathrm{~b}-$ General Fund operating revenues per capita \\
& $\mathrm{Y}_{4} \mathrm{c}-$ General Fund expenditures per capita \\
Service-level solvency & $\mathrm{Y}_{4} \mathrm{~d}-$ Debt Service Fund expenditures per capita \\
& $\mathrm{Y}_{4} \mathrm{e}-$ Capital Projects Fund expenditures per capita \\
\hline
\end{tabular}

Source: Maher, C.S. \& Nollenberger, K., 2009, Revisiting Kenneth Brown's 'Ten-Point Test' Government Finance Review. October 2009

The first three ratios were obtained from the MFMA Circular 71 (RSA, DOF 2014). For cash solvency, the cash ratio was used to measure the municipality's capacity to service its current debts by comparing its net cash flows from operating activities against its total debt service obligations. The higher the ratio, the greater the cash flow available to meet service delivery demands.

For budgetary solvency, the study used the operating ratio. This ratio determines the percentage of operating revenue that is available to the local government. The lower the ratio, the greater the restriction on the availability of funds for service delivery and the greater the dependency on grant transfers.

For long-term solvency, the long-term debt ratio was applied. This helps to determine the extent to which a local government entity can survive as a going concern. The higher the ratio, the lower the probability that the local government will survive as a going concern. Finally, for service delivery solvency, the study used capital projects per capita (Griesel \& Leatherman 2010). The higher the ratio, the greater the funds available for service delivery.

To determine the financial condition model, the financial condition function $g(x)$ was solved using the econometric Equation 2:

$\mathrm{g}(x)=\alpha_{1} x_{1}+\alpha_{2} x_{2}+\alpha_{3} x_{2}+\alpha_{4} x_{4}+\varphi$

[Eqn 2]

In this weighted-sum approach, the coefficients of the indicators are assigned according to their impact on the composite index (Greene 2003:257). The study selected LIMDEP $^{\circledR}$ as the econometric software to solve $\mathrm{g}(x)$ as a linear function of the form of Altman's (1968) Z-score and Ohlson's (1980) O-score. It is opposed to Coetzee and Kleynhans (2019) who, like Ritonga (2014), solved Equation 1 using the statistical analytical hierarchical process (AHP) of Saaty (1990) that results in a matrix outcome.

The financial condition function $\mathrm{g}(x)$ determines the coefficients $\alpha_{1}$ with density as the independent variable. Density was used for two main reasons. Firstly, it had limited noise $\varphi$ over a 5-year administrative period, thus reducing the 
error margin. Secondly, using density was appropriate as the national census had taken place in 2010, thus providing official population figures for the study that were not dependent on local government data.

Figure 2 illustrates how the financial condition score was constructed. Data were sourced from the National Treasury which provided the audited financial statements of 233 municipalities from the 2012 / 2013 to 2015 / 2016 fiscal years. During this period, there was a total population of 233 local and metropolitan municipalities in the country. This excludes district councils as they do not deliver direct services but support local municipalities. Thus, the study was not based on randomised population sampling. To provide service delivery solvency, statistical data were sourced from Statistics South Africa P9115 data sets for the delivery of water, energy, sanitation and roads. Figure 2 presents the normalisation and modelling process to solve for financial condition function $\mathrm{g}(x)$.

\section{Ethical consideration}

The data were sourced from the public domain in particular, the National Treasury and Statistics South Africa websites.

\section{Analysis and results}

Regression analysis was carried out on the individual four fiscal years and then as an aggregate of the 2012/2013$2015 / 2016$ data sets. This is the eigenvector that calculates the four eigenvalues which are the financial condition coefficients (or betas in LIMPDEP $^{\circledR}$ terminology). There were five audit disclaimers that reduced the number to 228 municipalities over the 4 years. The results can be found in Figure 3 .

\section{This gives rise to Table 2 .}

The financial condition function $\mathrm{g}(x)$ for South African local government is as follows:

$\mathrm{g}(x)=0.09$ Cash solvency +0.50 budget solvency -0.64

long-term debt -0.04 service delivery solvency [Eqn 3]
These individual municipal $\boldsymbol{\mu}$-scores with the following gradation scale were compared with Brown's (1993) original 10-point score and the Auditor-General's description (RSA, DOF 2012a) (see Table 3).

From Figure 4, it is clear that most municipalities fall between 0.28 and 0.57 , with a negative skewedness of -0.57 , which is less than -2 , making it a normal distribution. This indicates that although municipalities are on average doing well, they are becoming increasingly financially distressed. Thus, despite an inherently negative fiscal framework, municipalities endeavour to ensure that they become as financially sustainable as possible. This could be attributed to Operation Clean Audit (RSA, COGTA 2009b) and competency upskilling of chief financial officers through the Municipal Regulations on Minimum Competency Levels (RSA, DOF 2007).

The finding that $10.5 \%$ (or 24) of municipalities are financially sustainable aligns well to a study by Afrika Rating (2016) and confirms the findings of Mkhize (2018), who stated that only $7 \%$ of municipalities are financially healthy, and the rest were either in fiscal distress $(60 \%)$ or on the verge of becoming distressed. These figures exclude the five municipalities with audit disclaimers.

Table 4 shows that two peer-reviewed studies support the results of this research. The first is Ritonga's (2014) study on the financial condition index for Indonesian municipalities. His gradation scores for Indonesia are consistent with the findings of this study. This is of critical importance because Indonesia shares similar developmental attributes as South Africa.

The second peer-reviewed study is a South African study by Coetzee and Kleynhans (2019). Even though the study was limited to KwaZulu-Natal, it found the province to have an average index score between 0.40 and 0.44 . This score is compared to this research, which has shown that the average $\mu$-score for KwaZulu-Natal is 0.44 , as shown in Figure 5 .

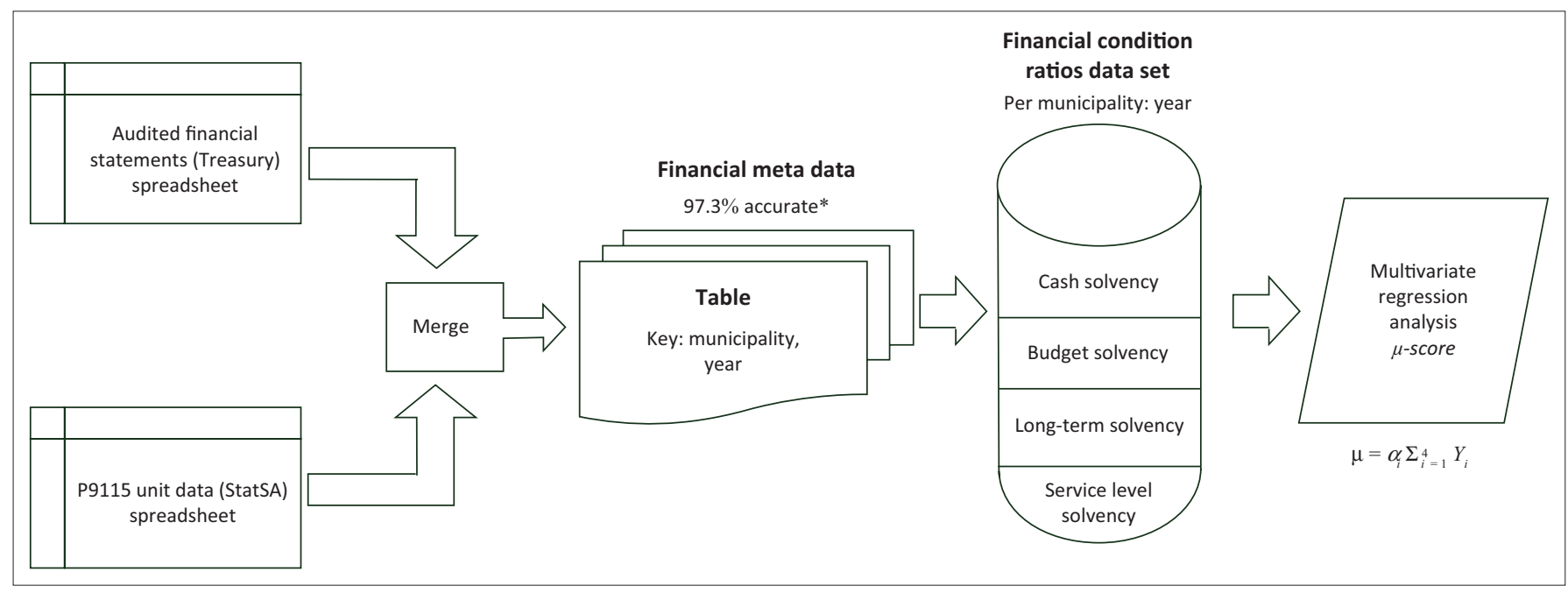

$*$, Less five municipalities with audit disclaimers.

FIGURE 2: Construction of the financial condition $\mu$-score. 


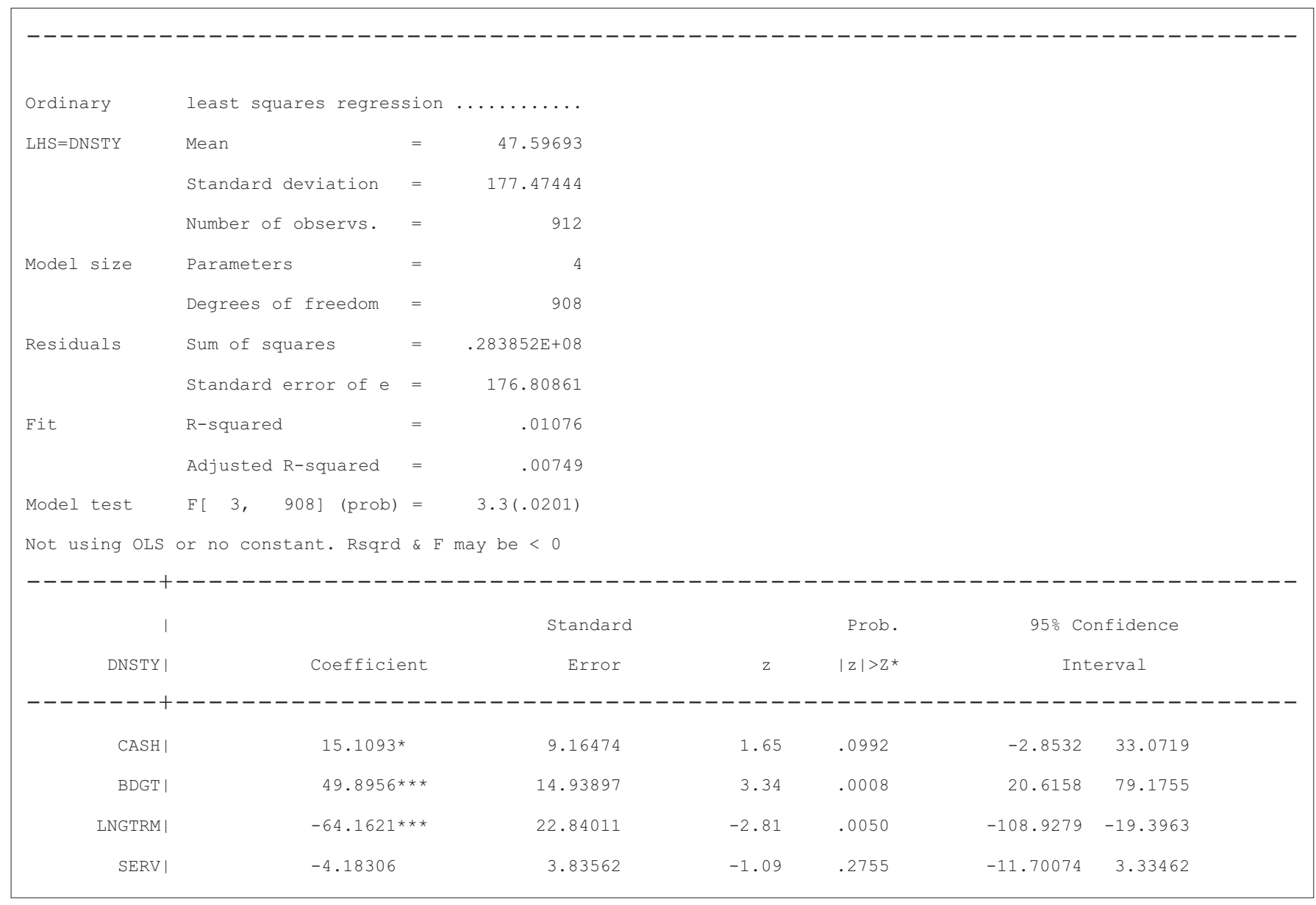

FIGURE 3: Calculation betas over the 4 years: 2012/2013-2015/2016.

TABLE 2: Coefficients of financial condition.

\begin{tabular}{lccccc}
\hline Variable & $\begin{array}{c}\text { FY } \\
\text { 2012/2013 }\end{array}$ & $\begin{array}{c}\text { FY } \\
\mathbf{2 0 1 3 / 2 0 1 4}\end{array}$ & $\begin{array}{c}\text { FY } \\
\mathbf{2 0 1 4 / 2 0 1 5}\end{array}$ & $\begin{array}{c}\text { FY } \\
\mathbf{2 0 1 5 / 2 0 1 6}\end{array}$ & 4-Betas \\
\hline Cash solvency & 9.45 & 14.84 & 17.27 & 18.10 & 9.16 \\
Budget solvency & 92.07 & 49.15 & 93.20 & 37.89 & 49.90 \\
Long-term solvency & -366.25 & -48.70 & -461.00 & -22.55 & -64.16 \\
Service delivery solvency & -2.83 & -6.03 & -3.46 & 9.17 & -4.18 \\
\hline
\end{tabular}

FY, fiscal year.

TABLE 3: Comparison of financial condition index with Brown's 10-point score.

\begin{tabular}{llll}
\hline Grade & Brown's score & $\mu$-score & Auditor-general \\
\hline Among the best & 10 or more & 0.50 to 0.60 & Excellent \\
Better than most & 5 to 9 & 0.40 to 0.49 & Above average \\
Average & 1 to 4 & 0.30 to 0.39 & Average \\
Worse than most & 0 to -4 & 0.2 to 0.29 & Below average \\
Among the worst & -5 or less & 0.19 and below & Poor \\
\hline
\end{tabular}

Therefore, the study supports the $\mu$-score as an absolute score applicable to the South African local government environment.

Converse to this study, Ncube and Vacu (2014), using Kloha et al.'s (2005) methodology, concluded that there was an improvement in the financial health of municipalities over the same period. This is supported by the skewness of the 139 out of 228 municipalities being above average. However, in reality, the fiscal health of municipalities has indeed regressed, contrary to their conclusion. This could

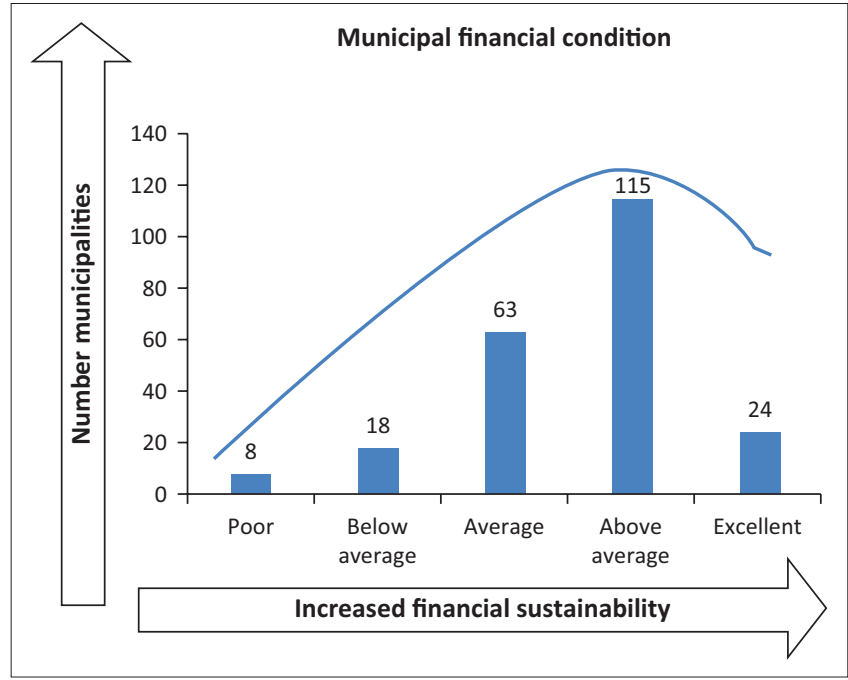

FIGURE 4: Financial condition by rank.

have been because Ncube and Vacu (2014), while using Kloha's method, did not use the standard GASB composite ratios recommended by Kloha et al. (2005). Rather, they opted to use conventional singular ratios from National Treasury under MFMA Circular 71 (RSA, DOF 2014) that do not include service-level solvency. This view supports the need to not only consider singular financial indicators, but also incorporate service delivery solvency as defined under financial condition (Figure 6). 
TABLE 4: Comparing Ritonga's index to the financial condition index.

\begin{tabular}{lll}
\hline Level of financial condition & Ritonga's FC index score & FC $\mu$-score \\
\hline Good financial condition & Higher than 0.51774 & $0.50-0.60$ \\
Average financial condition & Between 0.323707 and 0.51774 & $0.30-0.49$ \\
Poor financial condition & Less than 0.323707 & 0.29 and below \\
\hline
\end{tabular}

$\mathrm{FC}$, financial condition.

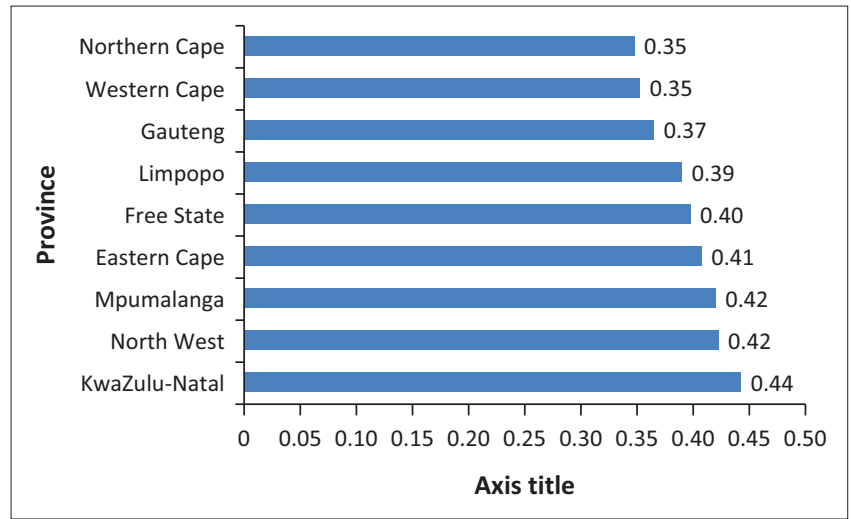

FIGURE 5: Average financial conditions by province over 4-year period.

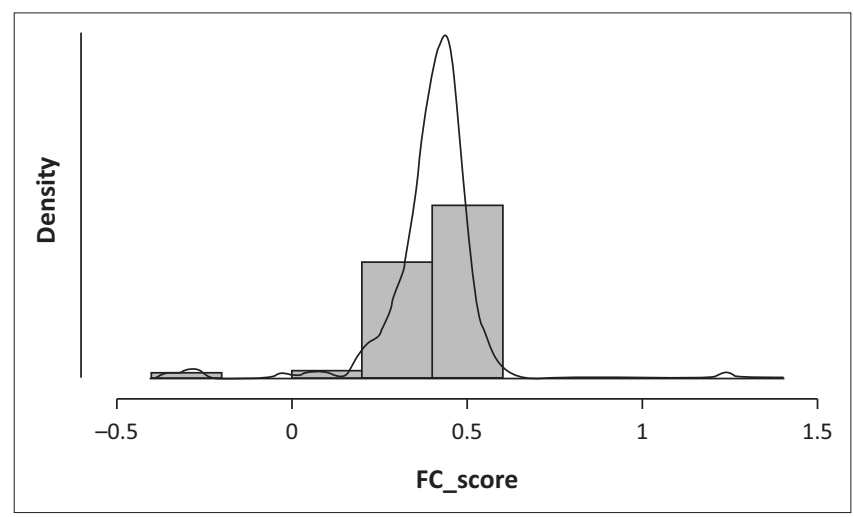

FIGURE 6: Normal distribution of financial condition scores.

Descriptive statistical analysis using principal component and reliability analyses gave the following determination on efficacy, robustness and consistency (see Table 5).

The principal component analysis (PCA) and the normal distribution chart show that the $\mu$-score is dependent on the population density of the local government; the greater the density, the higher the probability that it will be financially sustainable. This finding was similar to other studies in the United States (Ladd 1992; Wang et al. 2007). This is provided that the municipality does not enter into large long-term obligations, as in the case of the City of Johannesburg, with a $\mu$-score of 0.10 . The normal distribution chart further supports the efficacy of the results.

The reliability analysis performed a Cronbach's alpha test for the fiscal years 2012/2013 to 2015/2016, the results of which are presented in Table 6 .

The Cronbach's alphas for the respective years are shown in Table 7. An alpha score of more than 0.70 indicates that the results are reliable and consistent. The consistency spread
TABLE 5: Principal component analysis.

\begin{tabular}{lcc}
\hline Component loadings & RC 1 & Uniqueness \\
\hline Density & -0.746 & 0.443 \\
FC_score & 0.746 & 0.443 \\
\hline
\end{tabular}

TABLE 6: Scale reliability statistics.

\begin{tabular}{lc}
\hline Scale & Cronbach's $\alpha$ \\
\hline Reliability statistic & 0.738 \\
\hline Note: Of the observations, 228 were used, 0 were excluded listwise and 228 were provided. \\
TABLE 7: Cronbach's alphas for financial scores from $2012 / 2013$ to $2015 / 2016$. \\
\hline Year & Cronbach's $\alpha$ \\
\hline $2012 / 2013$ & 0.820 \\
$2013 / 2014$ & 0.752 \\
$2014 / 2015$ & 0.798 \\
$2015 / 2016$ & 0.700 \\
\hline
\end{tabular}

over the 4 years makes the financial condition function $\mathrm{g}(x)$ robust and reliable.

The results on financial condition that were used in this study offer a table of the $\mu$-scores for South African metropolitan and local municipalities (see Appendix 1). The single outlier, Tlkowe Local Municipality with a $\mu$-score of 1.24 , was removed from the table. With only one outlier from 228 municipalities, this indicates that the financial condition function $\mathrm{g}(x)$ is robust.

\section{Discussion}

The financial condition function $\mathrm{g}(x)$ for South African local government was solved as follows:

$\mathrm{g}(x)=0.09$ cash solvency +0.50 budget solvency -0.64

long-term debt -0.04 service delivery solvency

This solution supports Maher and Nollenberger's (2009) fiscal model that within the South African local government fiscal framework, the higher the $\mu$-score, the greater the financial sustainability of a municipality. It is observed that the absolute value of negative coefficients (0.68) is greater than those with positive attributes: cash and budget solvency at 0.59 . This means that the current fiscal framework of South African local government is negative or leads to greater fiscal distress. Thus, the dysfunctionality of local government should not only be viewed as a result of poor financial governance and lack of skills but also caused by an adverse fiscal framework.

On the positive side, although the fiscal framework for South African local government is distressed, most municipalities had a $\mu$-score between 0.30 and 0.52 . This indicates that despite fiscal pressures the drive by the National Treasury to enforce fiscal prudence is paying off. This supports Ncube and Vacu's (2014) conclusion of improved financial health but fails to explain the increasing fiscal distress recorded by the Auditor-General and the skewedness of -0.57 .

The financial condition function $g(x)$ 'long-term debt' variable has the greatest negative impact on the financial 
health of a municipality by a weight of 0.64. Thus, any increase in the financial indebtedness of a municipality will have an adverse impact on service delivery. This is observed in the 2012/2013 and 2014/2015 fiscal years when the Back to Basics Programme, aimed at increasing service delivery, was launched (RSA, COGTA 2014). The financial condition function $\mathrm{g}(x)$ indicates that the best way to offset this is through improved budgetary solvency as it has a positive impact on service delivery. This confirms the current research that the greatest threat for financial sustainability of South African local government is the ability to manage expenditure and long-term obligations (SALGA 2015).

The financial condition function $\mathrm{g}(x)$ shows that cash solvency has a limited impact on the financial sustainability of local government. This is contrary to the National Treasury's policy where it is used as a key financial indicator of liquidity, insisting that municipalities must have a 3 months' cash cover. Considering the constitutional mandate of local government is service delivery and not funds retention indicates that the financial condition function $g(x)$ reflects this mandate. However, it makes the ability of municipalities to have a budgetary solvency or cash-based budgeting crucial to achieve financial sustainability. This gives impetus to revisit National Treasury's traditional financial management approach as its success is limited (Hrüza 2013; Ntliziywana 2013).

Although the coefficient for service delivery is low at 0.04 it has a negative impact on the sustainability of local government entities. Thus, the greater the ability of a municipality to deliver services to its communities, the higher the probability that it will become fiscally distressed. This supports the observation that the provisioning of each utility (water, energy, sanitation and waste) is not cost reflective. This results in property tax subsidising lossmaking revenue streams. As a consequence, the annual increase in property tax exceeds other tariffs. This is contrary to MFMA Circular 64 (RSA, DOF 2012b), which assumes that, if well managed, these tariffs will result in improved revenue management.

A case in point of this skewed fiscal model is illustrated through service tariffs. Section 74(2) of the Local Government Municipal Systems Act (RSA 2000) states that tariffs must reflect the costs reasonably associated with rendering the service, including capital, operating, maintenance, administration and replacement costs, and interest charges in deriving revenue. In the case of Eskom, the largest energy supplier to municipalities, electricity cost tariffs (to the municipalities) are set at the start of the Eskom fiscal year in March, but the municipality can only implement demand price tariffs (to the consumer) at the start of the local government fiscal year in July. As a result, during the winter months between March and July, municipalities subsidise consumers for a product that they sell at below cost. Therefore, municipalities only receive $0.75 R$, where $R$ is the total revenue possible. This loss is further worsened by the
Pareto principle that states that $80 \%$ of the revenue is derived from the top $20 \%$ of the consumer base (Koch 1997). These are the large industrial businesses, such as mines, that have the highest price tariffs and revenue. However, they are Eskom's direct customers, leaving municipalities with commercial, government and residential customers with lower price tariffs and revenue. This maximum revenue is denoted by $0.8 R$ while dropping to $0.2 R$. Thus, $R_{\min }=0.15 R$ and $R_{\max }=0.60 R$. Maximum revenue $R_{\max }$ is not $100 \%$ because of lost streams that include the culture of non-payment among townships that are historically serviced by Eskom.

In the financial condition function $\mathrm{g}(x)$, this revenue settles the long-term debt variable such as with Eskom. With the highest coefficient of 0.64 it indicates that municipalities where Eskom has no presence are able to cover 0.60 of the long-term debt, leaving 0.04 of the debt settled by water and other levies. Where municipalities are mining towns, their ability to cover long-term debt remains with 0.49 of the longterm debt. With electricity more than $50 \%$ of revenue generated by municipalities, this leaves an outstanding 0.34 of the long-term debt weight not covered. This results in the municipalities at this low end of the spectrum spiralling into a fiscal quagmire. Even at the top end of the spectrum, the financial condition function $\mathrm{g}(x)$ shows that the collective debt is mathematically impossible to be liquidated without adversely affecting the health of the local governments. Consequently, the number of local governments that are unable to pay Eskom increases.

A press release from Eskom states that the debt by September 2018 stood at R34 billion of which 50\% is for the townships of Soweto. Möller (2019:1) in this press release states:

Municipal debt continues to rise, and this has become unsustainable. Municipal debt is no longer just an Eskom problem, it is a national problem.

The press release belies that when Eskom demand tariffs are plotted against the Consumer Price Index (CPI) from 1988 to 2017 , they have increased by $356 \%$ compared to CPI at $74 \%$ (Moolman 2018). This is indicative of poor financial governance.

Poor financial governance is further compounded when price tariffs are set in July; they are not cost reflective as high increases are absorbed by municipalities. This is synonymous to providing the service at a loss. Added to this, Eskom charges interest after 15 days on submission of invoice compared to the legislated 30 days. This results in irregular expenditure on the part of the municipality. When the municipality opts to pay as per legislation, the interest incurred is deemed wasteful expenditure. The municipal council is empowered to recoup the 'wasteful expenditure' from the Accounting Officer as prescribed in MFMA Circular 68 (RSA, DOF 2003).

The financial condition function $\mathrm{g}(x)$ shows that under the current local government fiscal regime, it is not possible for 
municipalities to comply with Section 74(2)(d) and (e) of the Local Government Municipal Systems Act (RSA 2000). Any expectations that at some point in the future Eskom will finally recoup monies owed by municipalities should be dispelled: there is no pot of gold at the end of the rainbow. This is exacerbated by the falling in prices for going off-the-grid solutions with the lifetime cost of energy (LCOE) dropping. For example, the City of Tshwane has an LCOE of R0.87/ kWh over 11 years. This is lower than the average municipal electricity costs of R1.09/kWh (Ayanna 2018). On the other hand, demand price tariffs keep escalating, making municipal energy services less and less economically attractive. This means that if the current fiscal framework is not reviewed, it could in the future result in an irreversible loss of municipal revenue as more consumers move off the grid.

In conclusion, despite the objectives of Section 73(2) of the Local Government Municipal System Act (RSA 2000), the financial condition function $\mathrm{g}(x)$ concludes that the current local government fiscal framework is not sustainable, leading to further fiscal distress even under good financial governance. Section 139(8) of the Constitution of the Republic of South Africa states that: 'National legislation may regulate the implementation of this section [on fiscal distress], including processes established by this section' (RSA 1996:98). The absence of legislation permits municipalities to invoke Section 151(4) of the Constitution of the Republic of South Africa (RSA 1996), which prohibits other spheres of government interfering in the affairs of a local government. This ambiguity in legislation makes placing a municipality under administration a political rather than administrative decision. An example is the City of Tshwane. With the lowest $\mu$-score of -0.02 , it should have been placed under administration in $2012 / 2013$. To avoid this scenario, it is proposed to draft legislation to effect Section 139(8) that is balanced against local governments' qualified autonomy enshrined in Section 151(3) of the Constitution of the Republic of South Africa (RSA 1996).

\section{Limitations}

The financial condition function $\mathrm{g}(x)$ is based on Maher and Nollenberger's (2009) methodology applied using econometric modelling. It captures the gradations of local governments' financial condition as well as putting them in a strong position to predict fiscal distress using general fund data. However, there is critique of Maher and Nollenberger's (2009) model, and econometric tools in general. These include Jones and Walker (2007) who posit that the use of general fund data is limited to closed financial systems and does not incorporate socio-economic conditions such as unstable or weak coalition governments. Their impact is incorporated into pseudo-open and open financial systems. This debate is best resolved by setting the parameters based on the objectives of the study in question (Dollery, Byrnes \& Crase 2007). The closed financial system of four financial ratios in this article offers an explanation as to why local governments in South Africa are becoming more and more fiscally unviable. This is despite the improvement in service delivery through increased community access to basic services.

\section{Conclusion}

Cooperative Governance and Traditional Affairs has implemented three initiatives: Project Consolidate (2004-2009), LGTAS (2009-2014) and the Back to Basics Programme (2014-2018). Their common aim was to address municipal financial sustainability, but none had tangible success. There is no indication about why the current Back to Basics Programme II of 2018 is expected to have a greater success without rectifying the fiscal structural defects. Thus, concurrent to addressing the lack of skills capacity and poor financial governance, a review of the fiscal framework needs to be made for municipalities to attain audit outcomes without material findings that are also financially sustainable. To address the skills deficit, the ANC as the ruling party should review its cadre deployment policy of 1996 by putting the interests of the state above those of the party.

The National Treasury's use of traditional measurements of financial position that apply singular ratios (RSA, DOF 2014) to determine financial sustainability have been eclipsed by the introduction of financial condition in 2004 which uses composite ratios (USA, GASB 2004). (This is the year after the enactment of the Local Government Municipal Finance Management Act [RSA 2003]). This article goes a step further by advocating the financial condition function $\mathrm{g}(x)$ to unpack fiscal structures that underpin financial condition. It is evident that National Treasury needs to overhaul its traditional financial management approach towards local government in order for it to truly become the face of democracy.

As the financial condition function $\mathrm{g}(x)$ illustrates, the National Treasury has to intervene in an increasing number of municipalities becoming financially unviable. This results in municipalities seeking financial support from national and provincial spheres by invoking Section 139 of the Constitution of the Republic of South Africa (RSA 1996), together with Section 150 of the MFMA (RSA 2003). As a result, it is difficult for bulk utility providers like Eskom to cut off services to municipalities because of non-payment.

The custodian of the MFMA is the National Treasury. This makes the National Treasury the architect of the local government fiscal framework. In its construction, it failed to acknowledge that local government has a transactional structure as opposed to the administrative nature of the other two spheres of government (national and provincial). As a result, the focus on the skills deficit as the de facto cause of poor financial governance undermines the National Treasury's ability to make appropriate structural reforms. If this is not attended to, it will reach such levels that the national fiscus can no longer support unsustainable local governments, as required by law. This, in turn, will adversely affect South Africa's sovereign rating. It could not have been 
better articulated than by the Minister of Finance, who said; 'South Africa's approach to tackling economic issues has not changed since the 1980's, even though society's structure has fundamentally changed' (Mboweni 2018).

In conclusion, fiscal research focuses on the modelling of financial condition per jurisdiction and analysing the resultant data. The assumption is that the fiscal framework is robust and conducive for sustainable local government. This article stresses the importance of constructing the financial condition function $g(x)$ as a mechanism to better understand the underlying fiscal structures. The article confirms that in the absence of an appropriate structure, financial condition analysis alone will not lead to financially viable local governments.

\section{Acknowledgements Competing interests}

The author has declared that no competing interest exists. views and opinions expressed in this article are those of the author and do not necessarily reflect the official policy or position of any affiliated agency of the author.

\section{References}

Afrika Rating, 2016, 60\% of key municipalities in financial trouble, viewed from https://www.moneyweb.co.za/...africa/60-key-municipalities-financial-troubleratings.

Altman, E., 1968, 'Financial ratios, discriminant analysis and the prediction of corporate bankruptcy', Journal of Finance 1986, 189-209. https://doi.org/ 10.1111/j.1540-6261.1968.tb00843.x

Ayanna, M.B., 2018, Energy autonomous campus solar PV plant procurement process, construction, performance monitoring and quality assurance, Centre for Scientific and Industrial Research (CSIR) Energy Centre, Johannesburg.

Ben-Elia, N., 1998, The municipal crisis in Israel: The management failure and the challenge of recovery, The Floersheimer Institute for Policy Studies, Jerusalem, Israel.

Berne, R. \& Schramm, R., 1986, The financial statement analysis, Prentice-Hall Press, New York.

Brown, K.W., 1993, 'The 10-point test for financial condition. Toward an easy-to-use assessment tool for smaller cities', Government Finance Review 9, 21-26.

Carmeli, A. \& Cohen, A., 2001, 'The financial crisis of the local authorities in Israel: A resource-based analysis', Public Administration 79(4), 893-913. https://doi.org/ 10.1111/1467-9299.00285

Chaney, B.A., Mead, D.M. \& Schermann, K.R., 2002, 'The new governmental financial reporting model: What it means for analyzing government financial condition', The Journal of Government Financial Management 51(1), 26.

Clark, T.N., Ferguson, L.C. \& Shapiro, R.Y., 1982, 'Functional performance analysis: A new approach to the study of municipal expenditures and debt', Political Methodology 8(2), 87-123.

Coe, C.K., 2008, 'Preventing local government fiscal crises: Emerging best practices', Public Administration Review 68(4), 759-767. https://doi.org/10.1111/j.15406210.2008.00913.x

Coetzee, C. \& Kleynhans, E., 2019, 'Modelling municipal financial conditions in KwaZulu-Natal - A unique Model for KwaZulu-Natal', Southern African Business Review 23(1), 1-25.

Dollery, B., Byrnes, J. \& Crase, L., 2007, 'Is bigger better? Local government amalgamation and the South Australian rising to the challenge inquiry', Economic Analysis and Policy 37(1), 1. https://doi.org/10.1016/S0313-5926(07)50001-9

Greene, W.H., 2003, Econometric analysis, Stern School of Business, New York University, Pearson Education, New York.

Griesel, J. \& Leatherman, J., 2010, Guide to financial condition indicators, viewed n.d., from www.ksu-olg.info/assets/docs/Guide_to_Fiscal_Indicators.pdf.

Groves, S.M., Godsey, W.M. \& Shulman, M.A., 1981, 'Financial indicators for local government', Public Budgeting \& Finance 1(2), 5-19. https://doi.org/10.1111/15405850.00511

Hrüza, F., 2013, 'Why traditional financial analysis tool and approaches are not suitable for municipalities and should be re-designed? (The case of municipalities in Czech Republic)', International Journal of Social Science and Humanity 3(1), 57-61. https://doi.org/10.7763/IJSSH.2013.V3.194
Jones, S. \& Walker, R.G., 2007, 'An alternative approach to identifying councils "at risk"', Economic Papers: A Journal of Applied Economics and Policy 25(4), 347-357.

Kalchheim, C., 1997, Local power in the context of the democratic state: The case of Israel, Jerusalem Center for Public Affairs, Jerusalem.

Kloha, P., Weissert, C.S. \& Kleine, R., 2005, 'Developing and testing a composite mode to predict local fiscal distress', Public Administration Review 65(3), 313-323. https://doi.org/10.1111/j.1540-6210.2005.00456.x

Koch, J.R., 1997, The 80/20 principle, Nicholas Brealey Publishing, London.

Ladd, H.F., 1992, 'Population growth, density and the costs of providing public services', Urban Studies 29(2), 273-295. https://doi.org/10.1080/00420989220080321

Maher, C.S. \& Nollenberger, K., 2009, Revisiting Kenneth Brown's 'Ten-Point Test'. Government Finance Review, October 2009.

Mboweni, T., 2018, 'The world has changed, we must change our mindset about the economy', News24, 21 October, viewed n.d., from https://www.fin24.com/budget/ mboweni-the-world-has-changed-we-must-change-our-mindset-abouttheeconomy/201810217.

Mercer, T. \& Gilbert, M., 1996, 'A financial condition index for Nova Scotia municipalities', Government Finance Review 12(5), 36-38.

Mhkize, Z., 2018, 'If we fix municipalities, half of the country's problems would be solved', Daily Maverick, 5 October, viewed n.d., from https://www.dailymaverick. co.za/opinionista/2081-10-05-if-we-fixed-municipalities-half-of-the-countrysproblems-will-be-solved/.

Möller, T., 2019, Eskom's distressed financial position and rising municipal debt pose a risk to the company's sustainability, Eskom Media statement of January 23, 2019, Pretoria.

Moolman, S., 2018, 350\% increase in a decade: How expensive is electricity in South Africa compared to other countries? viewed n. d. from www.poweroptimal. $\mathrm{com} / 350$-increase-decade-expensive-electricty-south-africa-compared-countries/.

Ncube, M. \& Vacu, N., 2014, Measuring fiscal distress in South African local government sector, pp. 110-140, Financial Fiscal Commission, Pretoria.

Netshitendzhe, J., 1996, 'The National Democratic Revolution - Is it still on track?', Umrabulo, Fourth Quarter 1996(1), 4-6.

Ngwenya, S., 2010, 'Evaluating financial conditions of local governments in South Africa - A case of metropolitan municipalities in Gauteng', International Research Symposium in Service Management 2010, Pointe aux Biches, Mauritius, August 24-27, 2010, n.p.

Nollenberger, K., 2003, Evaluating financial condition: A handbook for local government, International City County Management Association, Washington, D.C.

Ntliziywana, P., 2013, 'TMDB's Municipal Capacity Report: Is local government ready for National Treasury's deadline?', Local Government Bulletin 14(4), 3-6.

Nutt, P.C. \& Backoff, R.W., 1992, Strategic management of public and third sector organizations: A handbook for leaders, Jossey-Bass, San Francisco, CA.

Ohlson, J.A., 1980, 'Financial ratios and the probabilistic prediction of bankruptcy', Journal of Accounting Research 18(1), 109-131. https://doi.org/10.2307/2490395

Padovani, E., Manes Rossi, F. \& Orelli, R.L., 2010, The use of financial indicators to determine financial health of Italian municipalities, University of Bologna, Forli, $\mathrm{FC}$, Italy.

Powell, D.M., O'Donovan, M., Ayele, Z. \& Chigwata, T., 2014, Operation clean audit: Why it failed and what can be learned, University of the Western Cape, Cape Town.

Razin, E., 1998, 'The impact of decentralisation on fiscal disparities among local authorities in Israel', Space and Polity 2(1), 49-69. https://doi.org/10.1080/ 13562579808721770

Republic of South Africa (RSA), 1996, Constitution of the Republic of South Africa 1996, Government Printer, Pretoria.

Republic of South Africa (RSA), 1998, Municipal Structures Act 117 of 1998, Government Printer, Pretoria.

Republic of South Africa (RSA), 1999, Public Finance Management Act 1 of 1999, Government Printer, Pretoria.

Republic of South Africa (RSA), 2000, Municipal Systems Act 32 of 2000, Government Printer, Pretoria.

Republic of South Africa (RSA), 2003, Municipal Finance Management Act 56 of 2003, Government Printer, Pretoria.

Republic of South Africa (RSA), 2004, Public Audit Act 25 of 2004, Government Printer, Pretoria.

Republic of South Africa (RSA), Auditor-General of South Africa (AGSA), 2017, Auditorgeneral reports marginal improvements in local government audit results. [Media Release 21 June 2017].

Republic of South Africa (RSA), Department of Co-operative Governance and Traditional Affairs (COGTA), 2009a, The local government turnaround strategy, viewed n.d., from www.gov.za/documents/download.php?f=110100.

Republic of South Africa (RSA), Department of Co-operative Governance and Traditional Affairs (COGTA), 2009b, Address by the Minister for Cooperative Governance and Traditional Affairs, Min. Sicelo Shiceka, on the launch of the 2014 Clean Audit Project, viewed n.d., from www.gov.za/documents/ download.php? $\mathrm{f}=110100$.

Republic of South Africa (RSA), Department of Co-operative Governance and Traditional Affairs (COGTA), 2014, Back to basics approach, viewed n.d., from www.cogta.gov.za/wp/LG-Back-to-Basics-Approach-Document.pdf.

Republic of South Africa (RSA), Department of Finance (DOF), 2003, MFMA Circular 68: Unauthorised, irregular, fruitless and wasteful expenditure, viewed n.d., from mfma.treasury.gov.za/Circulars/Pages/default.aspx. 
Republic of South Africa (RSA), Department of Finance (DOF), 2007, Municipa regulations on minimum competency levels, viewed n.d., from mfma.treasury.gov. za/Circulars/Pages/default.aspx.

Republic of South Africa (RSA), Department of Finance (DOF), 2009, MFMA Circular 49. Annual report update, viewed n.d., from mfma.treasury.gov.za/Circulars/ Pages/default.aspx.

Republic of South Africa (RSA), Department of Finance (DOF), 2012a, Treasury circular 63. 'Predetermined strategic outcomes', viewed n.d., from mfma.treasury.gov.za/ Circulars/Pages/default.aspx.

Republic of South Africa (RSA), Department of Finance (DOF), 2012b, Treasury circular 64. Revenue management, viewed from mfma.treasury.gov.za/Circulars/Pages/ default.aspx.

Republic of South Africa (RSA), Department of Finance (DOF), 2014, Treasury circular 71. Uniform financial ratios and norms, viewed n.d., from mfma.treasury.gov.za/ Circulars/Pages/default.aspx.

Ritonga, I.T., 2014, 'Modelling local government financial conditions in Indonesia', Doctoral thesis, Victoria University Melbourne, Australia.

Saaty, T.L., 1990, 'How to make a decision: The analytic hierarchy process', European Journal of Operational Research 48(1), 9-26. Retrieved from https://doi.org/ 10.1016/0377-2217(90)90057-I
Schick, A., 1988, 'Micro-budgetary adoptions to fiscal stress in industrialized democracies, Public Administration Review 48(January/February), 523-533. https://doi.org/10.2307/975515

Schoeman, N., 2011, Fiscal performance and sustainability of local government in South Africa-An empirical analysis. (No. 201104), University of Pretoria, Pretoria.

South African Local Government Association (SALGA), 2015, Debt owed to municipalities. Critical success factors to billing, viewed n.d., from www.salga.org.za/.

Twala, C., 2014, 'The African National Congress (ANC) and the cadre deployment policy in the post-apartheid South Africa: A product of democratic centralism or recipe for a constitutional crisis?', Journal of Social Sciences 41(2), 159-165.

Wang, X., Dennis, L. \& Tu, Y.S.J., 2007, 'Measuring financial condition: A study of US states', Public Budgeting \& Finance 27(2), 1-21. https://doi.org/10.1111/j.15405850.2007.00872.x

United States Governmental Accounting Standards Board (GASB), 2004, Statement No. 44. Economic condition reporting, viewed n.d., from http://www.gasb.org/st/ summary/gstsm44.html.

Van der Waldt, G., 2012, 'Measuring the goodness of governance: Macro, intermediate and micro perspectives', African Journal of Public Affairs 5(1), 83-96.

Van Onselen, G., 2012, South African political dictionary, viewed n.d., from https:// inside-politics.org. 


\section{Appendix 1}

TABLE 1-A1: Financial condition scores by rank.

\begin{tabular}{|c|c|c|c|c|c|}
\hline Range & Number & Municipality name & Code & Density & $\mu$-score \\
\hline \multirow[t]{21}{*}{ 5: Among the best - excellent } & 1 & Steve Tshwete Local Municipality & MP313 & 57.80 & 0.60 \\
\hline & 2 & Umlalazi Local Municipality & KZN284 & 96.48 & 0.58 \\
\hline & 3 & Lukhanji Local Municipality & EC134 & 50.02 & 0.56 \\
\hline & 4 & Vulamehlo Local Municipality & KZN211 & 80.63 & 0.56 \\
\hline & 5 & Umngeni Local Municipality & KZN222 & 59.16 & 0.55 \\
\hline & 6 & Emthanjeni Local Municipality & NCO73 & 3.14 & 0.54 \\
\hline & 8 & Umtshezi Local Municipality & KZN234 & 42.17 & 0.53 \\
\hline & 9 & Kwa Sani Local Municipality & KZN432 & 6.96 & 0.53 \\
\hline & 10 & Uphongolo Local Municipality & KZN262 & 39.28 & 0.52 \\
\hline & 11 & Setsoto Local Municipality & FS191 & 18.87 & 0.52 \\
\hline & 12 & Ngquza Hill Local Municipality & EC153 & 112.43 & 0.51 \\
\hline & 13 & Abaqulusi Local Municipality & KZN263 & 50.43 & 0.51 \\
\hline & 14 & Victor Khanye Local Municipality & MP311 & 48.12 & 0.51 \\
\hline & 16 & Pixley Ka Seme Local Municipality & MP304 & 15.92 & 0.51 \\
\hline & 17 & Greater letaba Local Municipality & LIM332 & 112.48 & 0.50 \\
\hline & 18 & Emalahleni Local Municipality & MP312 & 147.67 & 0.50 \\
\hline & 19 & Modimolle Local Municipality & LIM365 & 14.65 & 0.50 \\
\hline & 20 & Blouberg Local Municipality & LIM351 & 17.59 & 0.50 \\
\hline & 21 & Emfuleni Local Municipality & GT421 & 747.06 & 0.50 \\
\hline & 22 & Greater Taung Local Municipality & NW394 & 31.52 & 0.50 \\
\hline & 23 & Mnquma Local Municipality & EC122 & 77.18 & 0.50 \\
\hline \multirow[t]{33}{*}{ 4: Better than most - above average } & 1 & Mhlontlo Local Municipality & EC156 & 66.61 & 0.49 \\
\hline & 2 & Emnambithi-Ladysmith Local Municipality & KZN232 & 80.08 & 0.49 \\
\hline & 3 & Midvaal Local Municipality & GT422 & 55.34 & 0.49 \\
\hline & 4 & Hibiscus Coast Local Municipality & KZN216 & 305.29 & 0.49 \\
\hline & 5 & Greater Kokstad Local Municipality & KZN433 & 24.62 & 0.49 \\
\hline & 6 & Buffalo City Local Municipality & BUF & 297.79 & 0.49 \\
\hline & 9 & Umdoni Local Municipality & KZN212 & 313.00 & 0.48 \\
\hline & 10 & Moqhaka Local Municipality & FS201 & 20.26 & 0.48 \\
\hline & 11 & Imbabazane Local Municipality & KZN236 & 79.29 & 0.48 \\
\hline & 12 & Kwadukuza Local Municipality & KZN292 & 314.54 & 0.48 \\
\hline & 13 & Elundini Local Municipality & EC141 & 27.27 & 0.47 \\
\hline & 14 & Lepelle-Nkumpi Local Municipality & LIM355 & 66.52 & 0.47 \\
\hline & 15 & Msunduzi Local Municipality & KZN225 & 975.61 & 0.47 \\
\hline & 16 & Gariep Local Municipality & EC144 & 3.78 & 0.47 \\
\hline & 17 & Umvoti Local Municipality & KZN245 & 40.97 & 0.47 \\
\hline & 18 & Newcastle Local Municipality & KZN252 & 195.81 & 0.47 \\
\hline & 19 & Kouga Local Municipality & EC108 & 36.91 & 0.47 \\
\hline & 20 & Lephalale Local Municipality & LIM362 & 8.40 & 0.47 \\
\hline & 21 & The Big Five False Bay Local Municipality & KZN273 & 16.62 & 0.47 \\
\hline & 22 & Sakhisizwe Local Municipality & EC138 & 27.00 & 0.47 \\
\hline & 23 & Greater Tubatse Local Municipality & LIM475 & 72.94 & 0.47 \\
\hline & 24 & Indaka Local Municipality & KZN233 & 103.95 & 0.47 \\
\hline & 25 & Thulamela Local Municipality & LIM343 & 103.08 & 0.47 \\
\hline & 26 & Dikgatlong Local Municipality & NC092 & 6.40 & 0.47 \\
\hline & 27 & Mbizana Local Municipality & EC443 & 116.63 & 0.47 \\
\hline & 28 & Govan Mbeki Local Municipality & MP307 & 99.67 & 0.46 \\
\hline & 29 & Ubuntu Local Municipality & NC071 & 0.91 & 0.46 \\
\hline & 30 & Emakhazeni Local Municipality & MP314 & 9.97 & 0.46 \\
\hline & 31 & Msukaligwa Local Municipality & MP302 & 24.83 & 0.46 \\
\hline & 32 & Kou-kamma Local Municipality & EC109 & 11.32 & 0.46 \\
\hline & 33 & Mtubatuba Local Municipality & KZN275 & 100.93 & 0.46 \\
\hline & 34 & Nquthu Local Municipality & KZN242 & 84.25 & 0.46 \\
\hline & 35 & Emadlangeni Local Municipality & KZN253 & 9.73 & 0.46 \\
\hline
\end{tabular}


TABLE 1-A1 (Continues...): Financial condition scores by rank.

\begin{tabular}{|c|c|c|c|c|c|}
\hline Range & Number & Municipality name & Code & Density & $\mu$-score \\
\hline & 36 & Ngwathe Local Municipality & FS203 & 17.08 & 0.46 \\
\hline & 37 & Kgatelopele Local Municipality & NC086 & 7.54 & 0.46 \\
\hline & 38 & Amahlathi Local Municipality & EC124 & 25.47 & 0.45 \\
\hline & 39 & Mandeni Local Municipality & KZN291 & 253.35 & 0.45 \\
\hline & 40 & Port St Johns Local Municipality & EC154 & 120.94 & 0.45 \\
\hline & 41 & Ndwedwe Local Municipality & KZN293 & 128.84 & 0.45 \\
\hline & 42 & Matatiele Local Municipality & EC441 & 46.84 & 0.45 \\
\hline & 43 & Aganang Local Municipality & LIM352 & 69.73 & 0.45 \\
\hline & 44 & Elias Motsoaledi Local Municipality & LIM472 & 67.16 & 0.45 \\
\hline & 45 & Mutale Local Municipality & LIM342 & 23.64 & 0.45 \\
\hline & 46 & Blue Crane Route Local Municipality & EC102 & 3.25 & 0.45 \\
\hline & 47 & Senqu Local Municipality & EC142 & 18.30 & 0.45 \\
\hline & 48 & Ekurhuleni Metropolitan Municipality & EKU & 1652.01 & 0.44 \\
\hline & 49 & Merafong City Local Municipality & GT484 & 121.10 & 0.44 \\
\hline & 51 & Swartland Local Municipality & WC015 & 30.69 & 0.44 \\
\hline & 52 & Lekwa Local Municipality & MP305 & 25.23 & 0.44 \\
\hline & 53 & Magareng Local Municipality & NC093 & 15.70 & 0.44 \\
\hline & 54 & Laingsburg Local Municipality & WC051 & 0.94 & 0.44 \\
\hline & 55 & Moses Kotane Local Municipality & NW375 & 42.41 & 0.44 \\
\hline & 56 & Maluti-a-Phofung Local Municipality & FS194 & 77.41 & 0.44 \\
\hline & 57 & Randfontein Local Municipality & GT482 & 314.29 & 0.44 \\
\hline & 58 & Tsolwana Local Municipality & EC132 & 5.47 & 0.44 \\
\hline & 59 & Nongoma Local Municipality & KZN265 & 89.33 & 0.44 \\
\hline & 60 & City of Matlosana Local Municipality & NW403 & 111.96 & 0.44 \\
\hline & 61 & Ngqushwa Local Municipality & EC126 & 32.21 & 0.44 \\
\hline & 62 & Matjhabeng Local Municipality & FS184 & 78.85 & 0.43 \\
\hline & 63 & Polokwane Local Municipality & LIM354 & 167.02 & 0.43 \\
\hline & 64 & Westonaria Local Municipality & GT483 & 174.64 & 0.43 \\
\hline & 67 & Lesedi Local Municipality & GT423 & 67.06 & 0.43 \\
\hline & 68 & Mafube Local Municipality & FS205 & 14.57 & 0.43 \\
\hline & 69 & Maruleng Local Municipality & LIM335 & 29.24 & 0.43 \\
\hline & 70 & Engcobo Local Municipality & EC137 & 62.61 & 0.43 \\
\hline & 71 & Greater Giyani Local Municipality & LIM331 & 58.54 & 0.43 \\
\hline & 72 & Stellenbosch Local Municipality & WC024 & 187.40 & 0.43 \\
\hline & 73 & Langeberg Local Municipality & WC026 & 21.63 & 0.43 \\
\hline & 74 & George Local Municipality & WC044 & 37.31 & 0.43 \\
\hline & 75 & Ulundi Local Municipality & KZN266 & 57.94 & 0.43 \\
\hline & 76 & Hlabisa Local Municipality & KZN274 & 46.25 & 0.43 \\
\hline & 77 & Mkhambathini Local Municipality & KZN226 & 70.87 & 0.43 \\
\hline & 78 & Richmond Local Municipality & KZN227 & 52.38 & 0.43 \\
\hline & 79 & Umzimvubu Local Municipality & EC442 & 74.36 & 0.43 \\
\hline & 80 & Bela Bela Local Municipality & LIM366 & 19.52 & 0.42 \\
\hline & 81 & Okhahlamba Local Municipality & KZN235 & 33.26 & 0.42 \\
\hline & 82 & Ba-phalaborwa Local Municipality & LIM334 & 20.19 & 0.42 \\
\hline & 83 & Musina Local Municipality & LIM341 & 9.02 & 0.42 \\
\hline & 84 & Intsika Yethu Local Municipality & EC135 & 53.62 & 0.42 \\
\hline & 85 & Letsemeng Local Municipality & FS161 & 3.93 & 0.42 \\
\hline & 86 & Tswelopele Local Municipality & FS183 & 7.30 & 0.42 \\
\hline & 87 & Metsimaholo Local Municipality & $\mathrm{FS} 204$ & 86.84 & 0.42 \\
\hline & 88 & Tsantsabane Local Municipality & NC085 & 1.91 & 0.42 \\
\hline & 89 & Sunday's River Valley Local Municipality & EC106 & 9.09 & 0.42 \\
\hline & 90 & Ndlambe Local Municipality & EC105 & 33.23 & 0.42 \\
\hline & 91 & Witzenberg Local Municipality & WC022 & 10.78 & 0.42 \\
\hline & 92 & Nketoana Local Municipality & FS193 & 10.75 & 0.42 \\
\hline & 93 & Maphumulo Local Municipality & KZN294 & 107.95 & 0.42 \\
\hline & 94 & Nkomazi Local Municipality & MP324 & 81.60 & 0.41 \\
\hline
\end{tabular}


TABLE 1-A1 (Continues...): Financial condition scores by rank.

\begin{tabular}{|c|c|c|c|c|c|}
\hline Range & Number & Municipality name & Code & Density & $\mu$-score \\
\hline & 97 & Umhlathuze Local Municipality & KZN282 & 421.76 & 0.41 \\
\hline & 98 & Mogalakwena local municipality & LIM367 & 49.90 & 0.41 \\
\hline & 99 & Ventersdorp Local Municipality & NW401 & 15.06 & 0.41 \\
\hline & 100 & King Sabata Dalindyebo Local Municipality & EC157 & 149.23 & 0.41 \\
\hline & 101 & Breede Valley Local Municipality & WC025 & 43.52 & 0.41 \\
\hline & 102 & Ga-segonyana Local Municipality & NC452 & 20.85 & 0.40 \\
\hline & 103 & Ditsobotla Local Municipality & NW384 & 26.13 & 0.40 \\
\hline & 104 & Masilonyana Local Municipality & FS181 & 9.32 & 0.40 \\
\hline & 105 & Nama Khoi Local Municipality & NC062 & 2.61 & 0.40 \\
\hline & 106 & Impendle Local Municipality & KZN224 & 21.67 & 0.40 \\
\hline & 107 & Dannhauser Local Municipality & KZN254 & 67.39 & 0.40 \\
\hline & 108 & Saldanha Bay Local Municipality & WC014 & 49.23 & 0.40 \\
\hline & 109 & Edumbe Local Municipality & KZN261 & 42.23 & 0.40 \\
\hline & 110 & Beaufort West Local Municipality & WC053 & 2.26 & 0.40 \\
\hline & 111 & Nkonkobe Local Municipality & EC127 & 35.06 & 0.40 \\
\hline & 112 & Kareeberg Local Municipality & NC074 & 0.66 & 0.40 \\
\hline & 113 & Mbhashe Local Municipality & EC121 & 80.44 & 0.40 \\
\hline & 114 & Dipaleseng Local Municipality & MP306 & 16.20 & 0.40 \\
\hline & 115 & Gamagara Local Municipality & NC453 & 15.89 & 0.40 \\
\hline \multirow[t]{42}{*}{ 3: Average } & 1 & Umzumbe Local Municipality & KZN213 & 127.86 & 0.39 \\
\hline & 2 & Ratlou Local Municipality & NW381 & 21.98 & 0.39 \\
\hline & 3 & Nkandla Local Municipality & KZN286 & 62.59 & 0.39 \\
\hline & 4 & Mamusa Local Municipality & NW393 & 16.70 & 0.39 \\
\hline & 5 & Cape Agulhas Local Municipality & WC033 & 9.53 & 0.39 \\
\hline & 6 & Lekwa-Teemane Local Municipality & NW396 & 14.47 & 0.39 \\
\hline & 7 & Mpofana Local Municipality & KZN223 & 20.94 & 0.39 \\
\hline & 8 & Makana Local Municipality & EC104 & 18.37 & 0.39 \\
\hline & 9 & Umuziwabantu Local Municipality & KZN214 & 88.66 & 0.39 \\
\hline & 10 & Thaba Chweu Local Municipality & MP321 & 17.20 & 0.39 \\
\hline & 11 & Overstrand Local Municipality & WC032 & 47.09 & 0.38 \\
\hline & 12 & Mogale City Local Municipality & GT481 & 270.06 & 0.38 \\
\hline & 13 & Maletswai Local Municipality & EC143 & 10.05 & 0.38 \\
\hline & 14 & Ingwe Local Municipality & KZN431 & 50.88 & 0.38 \\
\hline & 15 & Nala Local Municipality & FS185 & 19.67 & 0.38 \\
\hline & 16 & Mfolozi Local Municipality & KZN281 & 101.56 & 0.38 \\
\hline & 17 & Mantsopa Local Municipality & FS196 & 11.90 & 0.38 \\
\hline & 18 & Karoo Hoogland Local Municipality & NC066 & 0.39 & 0.38 \\
\hline & 19 & Bushbuckridge Local Municipality & MP325 & 52.80 & 0.38 \\
\hline & 20 & Umhlabuyalingana Local Municipality & KZN271 & 39.54 & 0.38 \\
\hline & 21 & Mangaung Metropolitan Municipality & MAN & 118.94 & 0.37 \\
\hline & 22 & Khara Hais Local Municipality & NC083 & 4.29 & 0.37 \\
\hline & 23 & Msinga Local Municipality & KZN244 & 71.00 & 0.37 \\
\hline & 24 & Ramotshere Moiloa Local Municipality & NW385 & 20.95 & 0.37 \\
\hline & 25 & Siyathemba Local Municipality & NC077 & 1.47 & 0.37 \\
\hline & 26 & Nyandeni Local Municipality & EC155 & 117.38 & 0.37 \\
\hline & 27 & Maquassi Hills Local Municipality & NW404 & 16.76 & 0.37 \\
\hline & 28 & Naledi Local Municipality & FS164 & 9.62 & 0.37 \\
\hline & 29 & Mkhondo Local Municipality & MP303 & 35.23 & 0.37 \\
\hline & 30 & Kgetlengrivier Local Municipality & NW374 & 12.85 & 0.37 \\
\hline & 31 & Knysna Local Municipality & WC048 & 61.91 & 0.37 \\
\hline & 32 & Endumeni Local Municipality & KZN241 & 40.29 & 0.37 \\
\hline & 33 & Albert Luthuli Local Municipality & MP301 & 33.46 & 0.36 \\
\hline & 34 & Tswaing Local Municipality & NW382 & 20.82 & 0.36 \\
\hline & 35 & Hessequa Local Municipality & WC042 & 9.18 & 0.36 \\
\hline & 36 & Mahikeng Local Municipality & NW383 & 78.83 & 0.36 \\
\hline & 37 & Umjindi Local Municipality & MP323 & 39.87 & 0.36 \\
\hline & 38 & Drakenstein Local Municipality & WC023 & 163.37 & 0.36 \\
\hline & 39 & Greater Tzaneen Local Municipality & LIM333 & 120.29 & 0.36 \\
\hline & 40 & Khai-Ma Local Municipality & NC067 & 0.75 & 0.35 \\
\hline & 41 & Phumelela Local Municipality & FS195 & 5.84 & 0.35 \\
\hline & 42 & Prince Albert Local Municipality & WC052 & 1.61 & 0.35 \\
\hline
\end{tabular}


TABLE 1-A1 (Continues...): Financial condition scores by rank.

\begin{tabular}{|c|c|c|c|c|c|}
\hline Range & Number & Municipality name & Code & Density & $\mu$-score \\
\hline & 43 & Sol Plaatjie Local Municipality & NC091 & 78.87 & 0.35 \\
\hline & 44 & Mbombela Local Municipality & MP322 & 109.16 & 0.34 \\
\hline & 45 & Kai Garib Local Municipality & NC082 & 2.50 & 0.34 \\
\hline & 46 & Rustenburg Local Municipality & NW373 & 160.55 & 0.34 \\
\hline & 47 & Bitou Local Municipality & WC047 & 49.56 & 0.34 \\
\hline & 48 & Mier Local Municipality & NC081 & 0.31 & 0.34 \\
\hline & 49 & Renosterberg Local Municipality & NC075 & 1.99 & 0.34 \\
\hline & 50 & Kheis Local Municipality & NC084 & 1.50 & 0.34 \\
\hline & 51 & Hantam Local Municipality & NC065 & 0.60 & 0.34 \\
\hline & 52 & Kopanong Local Municipality & FS162 & 3.14 & 0.33 \\
\hline & 53 & Dihlabeng Local Municipality & FS192 & 26.37 & 0.32 \\
\hline & 54 & Siyancuma Local Municipality & NCO78 & 2.21 & 0.32 \\
\hline & 55 & Nelson Mandela Bay Metropolitan Municipality & NMA & 588.11 & 0.32 \\
\hline & 56 & Umsobomvu Local Municipality & NCO72 & 4.16 & 0.32 \\
\hline & 58 & Madibeng Local Municipality & NW372 & 124.35 & 0.32 \\
\hline & 59 & Ikwezi Local Municipality & EC103 & 2.31 & 0.31 \\
\hline & 60 & Swellendam Local Municipality & WC034 & 9.37 & 0.30 \\
\hline & 61 & Mossel Bay Local Municipality & WC043 & 44.47 & 0.30 \\
\hline & 62 & Moretele Local Municipality & NW371 & 135.57 & 0.30 \\
\hline & 63 & Theewaterskloof Local Municipality & WC031 & 33.66 & 0.30 \\
\hline \multirow[t]{16}{*}{ 2: Worse than most - below average } & 1 & Matzikama Local Municipality & WC011 & 5.17 & 0.29 \\
\hline & 2 & Mohokare Local Municipality & FS163 & 3.89 & 0.29 \\
\hline & 3 & Tokologo Local Municipality & FS182 & 3.11 & 0.29 \\
\hline & 4 & Ephraim Mogale Local Municipality & LIM471 & 61.49 & 0.29 \\
\hline & 5 & Great Kei Local Municipality & EC123 & 22.46 & 0.29 \\
\hline & 6 & Inkwanca Local Municipality & EC133 & 6.13 & 0.28 \\
\hline & 7 & Nxuba Local Municipality & EC128 & 8.88 & 0.27 \\
\hline & 8 & Naledi Local Municipality & NW392 & 9.62 & 0.27 \\
\hline & 11 & Bergrivier Local Municipality & WC013 & 14.05 & 0.25 \\
\hline & 12 & Baviaans Local Municipality & EC107 & 1.52 & 0.24 \\
\hline & 13 & Ethekwini Metropolitan Municipality & ETH & 1501.90 & 0.24 \\
\hline & 14 & Joe Morolong Local municipality & NC451 & 4.44 & 0.23 \\
\hline & 15 & Ubuhlebezwe Local Municipality & KZN434 & 63.40 & 0.22 \\
\hline & 16 & Ntabankulu Local Municipality & EC444 & 89.51 & 0.22 \\
\hline & 17 & Dr JS Moroka Local Municipality & MP316 & 176.35 & 0.21 \\
\hline & 18 & Phokwane Local Municipality & NC094 & 7.55 & 0.20 \\
\hline \multirow[t]{8}{*}{ 1: Among the worst - poor } & 1 & City of Cape Town Metropolitan Municipality & CPT & 1529.66 & 0.19 \\
\hline & 2 & Oudtshoorn Local Municipality & WC045 & 27.12 & 0.19 \\
\hline & 3 & City of Johannesburg Metropolitan Municipality & $\mathrm{JHB}$ & 2695.94 & 0.10 \\
\hline & 4 & Inxuba Yethemba Local Municipality & EC131 & 5.62 & 0.05 \\
\hline & 5 & Fetakgomo Local Municipality & LIM474 & 84.88 & -0.34 \\
\hline & 6 & Kamiesberg Local Municipality & NC064 & 0.72 & -0.29 \\
\hline & 7 & Thabazimbi Local Municipality & LIM361 & 7.62 & -0.27 \\
\hline & 8 & City of Tshwane Metropolitan Municipality & TSH & 460.44 & -0.02 \\
\hline
\end{tabular}

